\title{
The Origins of Energy Security: British Energy Policy in the Middle East (Selling the Same Horse Three Times!)
}

Ioannis VIDAKIS, Department of Shipping, Trade and Transport, Aegean University, Greece; e-mail: johnvidos2000@yahoo.gr

\section{Enerji Güvenliğinin Doğuşu: Orta Doğu'da İngilizlerin Enerji Politikası (Aynı Atı Üç Defa Satmak)²}

\begin{abstract}
This specific text focuses on UK energy policy. It attempts to link the past to the present by making a short story focusing on energy sources. The United Kingdom has decided to use the «black gold» in warships, with a serious risk: it didn't have its own inventory and had to look for it elsewhere. The decision of Britain involved countries and people of the wider Middle East in support of its energy interests for many years.

Keywords $\quad$ : Energy, Energy Resources, Energy Policy, Energy Security, British Energy Policy, Middle East.

JEL Classification Codes : $\quad$ A12, F34, F50, N70, Q480.

$\ddot{O} z$

Bu çalışma İngiltere'nin enerji politikasını bağlamında, enerji kaynaklarının geçmişten günümüze doğru gelişimini ele almaktadır. İngilizler kendi savaş gemilerinde "kara altın" kullanmaya karar verdiklerinde ciddi bir riskle karşı karşıya kaldılar: kendilerinde yeteri kadar kaynak yoktu ve başka bölgelerden bunu tedarik etmeleri gerekiyordu. İngilizler kendi enerji çıkarları uğruna yıllarca Orta Doğu bölgesindeki halklara ve ülkelere müdahale ettiler.

Anahtar Sözcükler $\quad$ : Enerji, Enerji Kaynakları, Enerji Politikası, Enerji Güvenliği, İngiliz Enerji Politikası, Orta Doğu.

1 Paper presented in "International Congress on Energy Security in Eastern Mediterranean" which was held by Hacettepe University Center for Energy Markets Application \& Research, in Mersin / Turkey, on December 1416, 2013.

2 Bu çalışma, Hacettepe Üniversitesi Enerji Piyasaları Uygulama ve Araştırma Merkezi tarafindan 14-16 Aralık 2013 tarihinde Mersin'de düzenlenen “Uluslararası Doğu Akdeniz'de Enerji Güvenliği Kongresi”nde tebliğ olarak sunulmuştur.
\end{abstract}




\section{Introduction}

The energy policy of a state is mostly defined by its national interests, which in turn they are mainly specified by its needs. Hence, a country can: consume energy, (which imports when its own sources don't suffice to cover it). Produce energy resources, (which injects to foreign markets in the corrective that they over cover the domestic demand). Transmits - transfers hydrocarbon, [through territory (pipelines) and its flag, (commercial fleet)].

Historically British in 1912 took the decision to use oil in its naval fleet in order to be able to confront the growing navy of its geo-political opponent Germany - (changing from the energy safe Welsh coal to the unstable Persian oil). Nevertheless it didn't have autonomy, (internal sources of oil) as the USA for example. So ever since, it structured and formed its foreign and diplomatic policy, with main shaft the assurance of its access to the energy resources of other countries till 1973, when the commercial exploitation of the North Sea deposits was achieved.

However the rapid exhaustion of its deposits of oil combined to the obsessive mistaken decisions of its political leadership; endanger it to fall off the category of the great European power, with aspirations of dominance on issues and regions, to a state of energy deficiency. As a result its example is extremely instructive: regarding the issues of geopolitics and geo-energy possible errors are endeavoured on long-term basis, in a painful way (Karkazis, Vidakis \& Baltos, 2010: 107-109). Of course the reaction of the United Kingdom is expected to be interesting in that case - it has a rich experience from the past, where it managed to control the oil quantities that it needed, without being itself an oil production country.

The next period of time is reasonably expected to be developed to a period of increased turmoil in the front of the wider region of the Middle East. This region is basically the "geo energy deposit" of the planet. Focus and target the energy reserves in the Eastern Mediterranean seabed. In this geopolitical canvas, strategic and financial interests, competitions and benefits are interrelated. The substantial operation of the European Union in its neighboring space, can effectively contribute to the growth of all the states, with common benefits for all. Key policy is the activation of the Euro Mediterranean cooperation with centers - links the Mediterranean islands, (Sardinia, Malta, Crete, Cyprus), the application of the rules of the international law and the cooperation with the neighboring Arab countries and Israel. 
Vidakis, I. (2015), “The Origins of Energy Security: British Energy Policy in the Middle East (Selling the Same Horse Three Times!)", Sosyoekonomi, Vol. 23(25), 31-45.

\section{British Energy Policy in the Middle East}

The group "Royal Dutch Shell” was founded in February of 1907. The Dutch company "Royal Petroleum" and "Shell Transport and Trading Company Ltd" of the United Kingdom, merged their activities in order to be able to compete at world level with, the then dominant American oil company, "Standard Oil" by John D. Rockefeller. Bakanakis, Litsis, and Ketantzidis (2010: 303) refer that the merger terms attributed "the 60\% of the group's property to the Dutch sector and the $40 \%$ to the British". Note that Rockefeller initially attempted to buy off the "Royal Petroleum" but the Dutch president Henri Deterding ${ }^{3}$ denied. He finally associated with the previously mentioned small shipping firm of the Far East, in order to cope with the lack of funds and the needs of the oil maritime transfer (from the Dutch East Indies - Indonesia, where the company operated). It was a transport and commercial company of shells after which it was named: "Shell". Its founder was the Jew Marco Samuel. It had no big funds, nor great ships for the oil transport that Deterding needed. However its funds and ships had a big advantage: were housed under the English flag. At that time, when the use of fuel oil for heating was spread and the ships had started using oil, it was the most powerful state of the world (British Empire), which was basing its power on its naval supremacy.

From oil and for oil began the intense fight for dominance, between the allied in strong trusts capitalists, with governmental interventions too. Britain had no oil wells so supported Deterding and his group. It helped him with all the appropriate means to confront Rockefeller's powerful oil empire. The power balancing to the undeclared war of oil allowed London to breath. It is characteristic the spread of the "Royal Dutch" in Romania (1906) and then of the "Royal Dutch Shell Group" in Russia (1910), in Egypt (1911), in the USA, (1912 and 1915), in the Ottoman Empire (it participates with $25 \%$ in the Turkish Petroleum Company in 1912), in Venezuela (1913), in Trinidad (1914), in Mexico (1918). In a letter (13 July 1913) from Admiral of the Fleet 1st Lord John Fisher [Chairman, Royal Commission on Oil Fuel] to WSC [Winston Spencer Churchill, First Lord of the Admiralty] on oil supply, urging him not to quarrel with Henri Deterding [Director, Shell Oil Company], "The greatest man I have met", suggesting that WSC make a contract with him for the use of his fleet of 64 oil tankers in case of war (Churchill College. Official: Admiralty: Admiral of the Fleet 1st Lord Fisher: Correspondence. Reference code: CHAR 13/21). Already

3 At first he was President of the "Royal Dutch" and then of the group "Royal Dutch Shell” - for 36 years (19001936). The British nominated him "Sir" in 1920, for his contribution to the WW I. During the '30s he became an admirer of the German Nazi party. In 1936, he discussed with the Germans the sale of oil reserves, for a year on credit. The following year, he was forced to resign from the board of directors of the company. (See for details: Donovan, 2010). 
situated since 1882 in Egypt, the British captain John Fisher strongly supported the use of oil instead of coal in the British naval force. He supported that the operational ability of the fleet would immediately increase at 50\%, (flexibility, reduced logistics dependence, cost savings of combat personnel) - nevertheless he was initially treated by his supervisors with indifference. Engdahl (2007) states that in 1904 Fisher undertakes command of the British Admiralty and attempts to apply his ideas - cause of his obsession to oil use, he is called by his colleagues: «oil maniac».

Tsakiris (2008: 269) indicates that the Fuel Oil Committee was established in November of 1904 and the most important proofs of conversion and reinforcement of this policy, [to a genuine based on commercial (mercantilist) direction, that the German economist, (enthusiast of the initial protectionism of an economy) Friedrich List would easily applaud] were:

(a) The decision of 1904 of the British Colonial Office by which it was forbidden the majority shareholding in consortium that would be founded in the imperial territory for oil exploration and exploitation by non- British citizens

(b) The assurance of the fact that the most promising operation of new oil reserves exploitation east to Suez, (in today's Southwest Iran), would remain under the control of the British interests, despite the fact that this area was outside the official limits of the Empire.

The latter specific historical event was the first expression of the British oil diplomacy in a country where after half a century, the nationalization of the oil investment by the Prime Minister Mossadeq, would mark the begining of the end of Britain as an autonomous Great Power in the region of the Middle East. More extensively the weak company of oil exploring since 1901 in Southwest Iran (Shustan district) ${ }^{4}$ had started facing serious cash flow problems. The Fuel Oil Committee assured the support of the Admiralty and the Ministry of Foreign Affairs for the salvation of the firm. The British Ministry of Foreign Affairs at first appeared hesitant to support the company, but later foresaw the danger of the company's by hostile interests, in the crucial geostrategic region of the Persian Golf. The Minister of Foreign Affairs, Lord Lansdowne, had announced at the House of Commons already since May 1903 that: "the British government would consider the creation of a naval base or fortified port in the area of the Persian Gulf as an extremely serious threat to the British interests, to which it would resist for sure and by all means". However D'

\footnotetext{
4 It was controlled by the "First Exploration Company", of the businessman William Knox D'Arcy.
} 
Arcy's lending application rejected by the Finance Minister in 1903 and made him ask for financial support from French (through Rothschild's) and American funds (through Standard Oil). Fisher's appointment as head of the Admiralty was to save D'Arcy's company, for the support of the British interests as the naval Anglo-German competition was peaking. According to Tsakiris (2008: 271) "the approach with which this salvation was organised was the product of the orientation, the final planning and political persistence of several factors: firstly of the British Admiralty, under Pretyman and Fisher for clearly operational reasons and secondly of the Ministries of Foreign Affairs and Colonial Issues for the geopolitical reasons that are crystallized in the mentioned before note by Lansdowne".

Initially it was assured that D' Arcy would not proceed to an understanding with non- British interests while the Admiralty would take over the setting-up of a so-called "patriots' union" - a partnership of interests, for the operation of the company. Yergin (1992: 141) states that "the millionaire Lord Strathcona, was convinced to take over the presidency of the "union" while he was already president of the British oil company Burmah Oil (established in Glasgow), which was active since 1886 in the British Indies edges, developing a distribution kerosene net". Till 1904 cause of the official integration of Burma (Myanmar) to the Indies in 1885, the company was considered safe and it was handed over a catering contract of the British navy. Its shareholders received in addition as reassurance of their investments, "the confirmation- under urgings of the Admiralty -from the Ministry of Foreign Affairs, that Persia could be considered as a region under the British protection". Till May of 1905 the pressure of the responsible Ministries of the British Empire established a new partnership, the "Concessions Syndicate Ltd". Bakanakis et al., (2010: 305) write "this new firm took over the exploitation of D'Arcy's concession, finding within the next two years significant resources, renamed in 1909 "Anglo-Persian", (located in London), being till its nationalization in 1914, the only controlled by the British reliable supply source of the imperial navy".

Quantitatively this energy source was never enough for the needs of the British. The oil under the direct or indirect control of Britain corresponded to just the $2.5 \%$ of the world production for 1912. That year USA controlled the $63.3 \%$, Tsarist Russia the $19.4 \%$ and Mexico which was under the Monroe Doctrine, the 4.7\%. Tsakiris (2008: 278) reports that "when the war burst the hegemonic position of the USA remained unshakeable, as it controlled the $65 \%$ of the world production, Russia the $18 \%$, Mexico the $6.4 \%$, Romania the $3.1 \%$, the Dutch Indies - which were the base of the "Royal Dutch/Shell" dominance the $2.79 \%$ and just the $0.7 \%$ the Anglo-Persian investment in Southwest Persia". Besides that, the British final planning, as well as the one of the other Great Powers which was on the verge of the WW I considered that the strategic utility of oil was simply restricted to the sector of naval force. 
The British Admiralty and the Ministry of Foreign Affairs succeeded in reassuring the control in Southwest Persia, as a result of the Iranian Revolution of 1906 and the Russian-British Entente, (Treaty of Saint Petersburg in August 1907). However the internal political developments acted as a barrier to the completion of the implementation plan for the complete oil use of the fleet and the Dreadnought type super warships. In more details the government of the Liberals was emerged from the December elections of 1905, with a more neutral strategy against Germany and a program of reduction military expenditures for social policy. The Fuel Oil Committee was dissolved by the early 1906. After 1908 the economists of the Asquith government, made every effort to fight the extended but costly naval program of Fisher. As Yergin (1992: 153) particularly points out: "Churchill and Lloyd George defended an Anglo-German naval agreement as a mean to limit the navy's expenditures and to save funds for the [reinforcement] of the social reform". Fisher finally retired in 1910.

However with the new Conservative government of November 1911, the Admiralty managed to complete its plans: oil use to warships and were initially ordered five diesel warships of large displacement. What caused this change of policy, which had already started to be implemented before the collapse of the Asquith government, through Churchill's appointment, as higher political supervisor of the Admiralty? In September 1911 the newly appointed Churchill, one of the leaders of the «liberal economists» fully gave in to the policy of the previous year retired Admiral Fisher. According to Christodoulidis (1997: 407) "the turning point for the emergence of the strategic utility of oil as dominant supplier of the British navy seems to be traced on the geostrategic causes of the Second Moroccan crisis of Agadir in the summer of 1911: the empty show of force by the German navy through the shipping of the warship "Panther" to the Moroccan port, managed to bring together the whole of the anti-German coalition in London, underlining the size of the German challenge and the potential threat to the British sea dominance”.

As Churchill pointed out in his memoirs of the WW I regarding the greatness of the German naval threat: "The whole of the fortunes of our nation and Empire...the whole of the accumulated wealth through all these centuries of sacrifices and achievements, will be lost, will be swept utterly away if our naval superiority was to be weakened". The main argument instead - as Churchill admitted in public consultation in the House of Commons in March 1912, was trace on that, unlike USA the British islands and the whole British Empire, didn't have significant oil reserves. It has been argued (Tsakiris, 2008: 274) that "the operational however advantages that guaranteed for the war vessels the oil combustion were overwhelmingly superior to the political risk that its production implied too far away and possibly hostile environments, such as the Persian Gulf". 
Churchill then, (July 1912) established - the first state official committee of "Energy Safety" in the history, under the well known John Fisher. The Royal Commission on Oil and the Oil Engine supported the same year Churchill's proposal for diesel engines use by the navy and received the approval of the British government for a series of decisions that led to:

(a) the implementation of the biggest till then armament program in the history of the British navy (1912-1914), with the construction of six diesel engines dreadnoughts,

(b) the creation of the first strategic oil reserve, of four years for the needs of the navy,

(c) the immediate redemption of the $51 \%$ of the "Anglo-Persian", by the British state on 20 May $1914^{5}$, first direct investment of the state outside the British Empire.

For Britain, cause of the domestic oil sources lack, the biggest possible differentiation of the alternative import sources, was the most important mean for the covering of the energy safety needs of the empire's navy. As Churchill said, "we cannot depend on just one quality, on just one process, on just one country, on just one passage [of imports] and on just one field [of production]. The safety and security of oil are only found in variety. Our goal is to import our oil, where possible, from sources under British control or influence along to those ocean roads, which our navy can protect as easily and prepare as possible".

Churchill, as First Lord of the Admiralty, placed funds of the Admiralty to the oil companies, provoking his country's politicians. He was justified though because soon the WW I started at the end of which the Minister of Foreign Affairs of the United Kingdom Lord Curzon claimed that the Allies won "floating in oil ocean's waves".

In the WW I Britain since November 1914 arranged for the occupation of Basra and South Iraq by General Nixon's forces. The mission was the securing of the strategic reserves of the British navy in Abadan by a possible German-Ottoman attack and the defence of these positions during the Ottoman attacks in the spring of 1915. Then on April 15, 1915, London attempted to take control of the Ottoman Empire, (and through this sovereignty in Arab areas), directly harming Constantinople, preventing the Russians, (landing in a small

5 The following month the motive for the outburst of the World War I was given. 
bay at the western tip of the Gallipoli peninsula - that it is officially named today, Anzac Cove). The campaign reached an impasse with the withdrawal of forces by the end of the year.

Britain was not daunted and in the existing context - the secret Sykes-Picot agreement is included ${ }^{6}$. It concluded on May 16, 1916 between the governments of the United Kingdom and France, with the consent of the Tsarist Russia. It defined the respective spheres of influence and control in the Middle East, following the expected collapse of the Ottoman Empire during the WWI. Note that the original approach of British geopolitics in the distribution areas motivated them to give the territories of Mosul (northern Iraq) in France. This was for the "protection" of their sovereignty from an intermediate French region, so that they do not border with their geostrategic opponent of imperial Russia.

(We note that, as early as 1904, the British Halford John Mackinder had published his geopolitical theory of «Heartland», by January 1910 he was elected member of Parliament and therefore he could influence the shaping of British policy). However the British had not estimated the oil of Mosul. Earlier, UK had encouraged the Arabs to revolt against the Ottoman Empire. (Repeated exchange of letters in the period: July 14, 1915 to 30 January 1916, between the Sharif of Mecca, Sayyid Hussein bin Ali, (1854 - 1931) and Sir Henry McMahon ${ }^{7}$, British High Commissioner in Egypt, on the future political status of Arab Asian territories which stated that the Arabs would revolt in alliance with the United Kingdom and in return Britain would recognize their independence). The Ottoman Empire was "swept away" by the skilful UK, in an alliance with the Germans in the summer of $1914^{8}$. The policy of UK related to ensuring the prevalence of British sovereignty in the Middle East, with the reserves of oil. When, after the Russian Revolution of October 1917, the Bolsheviks denounced the secret diplomacy and publicized the documents, including the Sykes-Picot agreement, the Arabs informed that they had been betrayed. Yergin (1992: 188) states that "London beyond the embarrassment, made the conquest of the oil reserves of Mosul - (northern Iraq) - a "first degree military objective" (as then, there was no danger to

6 Mark Sykes was an English politician, specialist in Eastern issues, researcher on the Ottoman Empire. Member of the British Parliament and later British Government's envoy to the Middle East. George Picot was the French Consul General of France in Syria before the WWI. The headquarters was in Beirut. He was appointed as an envoy of the French government in the same area and in charge of negotiations with England for the future of Arab countries. See the text of the agreement in Hurewitz, 1979.

7 See the text of letters Hussein kol McMahon in the books: Holt, 1966, 264-270; Antonius, 1969, 413-427; Hurewitz, 1979, 46-56.

8 In an unpublished document of the writer, on the successful escape to Constantinople of the German cruisers Goeben and Breslau in the summer of 1914. 
border by the Russians), although under the agreement they had granted Mosul to the allies French".

After the public complaint from the Bolsheviks to Sykes-Picot agreement, the Declaration of UK Foreign Secretary Balfour followed, (November 1917). It was a diplomatic letter to Walter Rothschild, leader of the British Jewish community, shaping expectations for the future establishment of a Jewish state in Palestine (Sidebothan, 1938: 50-53). In August 1918, Balfour said that Britain should be the "guiding spirit" in Mesopotamia, to provide a key resource in the British Empire and noticed: "I do not care about the system as long as we have enough oil". In December 1918 Britain signed an agreement with France known as Clemenceau - Lloyd George Agreement, with which Mosul was annexed to English influence ${ }^{9}$. British forces occupied the region - a key north of Mosul after the armistice of Mudros, signed with the Ottomans. They brought French interests in the oil zone in Northern Mesopotamia in an accomplished fact. Paris vehemently opposed because of the shortage of domestic energy sources. Politicians and army forces had great expectations of Mesopotamia being a key resource for the development of future industrial and military power.

So after the truce, the issue of oil caused much friction between the two allies. During the negotiations of the peace of Versailles, the British Prime Minister Lloyd George and French counterpart fought about the issue of Mesopotamia (Iraq) for oil and US President Wilson intervened. Tsakiris (2008: 401) notes that "later in the secret San Remo Agreement of April 1920, the two rivals approved of Britain taking over the political control in Mesopotamia in return for British support: French sovereignty to Lebanon and Syria, ensuring $25 \%$ of Iraqi oil production in positive price and the assumption by France of the German share in the Turkish Petroleum Company (TPC)". The latter was established in 1912 to explore oil in Ottoman Mesopotamia. Its shareholders were a group of major European companies - Deutsche Bank with 25\%, the Anglo Saxon Oil Company, (subsidiary of Royal Dutch / Shell) with 25\%, the National Bank of Turkey (British interests) with $45 \%$ and an Armenian entrepreneur Calouste Gulbenkian with 5\%. In 1914 the British owned AngloPersian Oil Company took over the $45 \%$. [The TPC had received promissory concession in the region of Mesopotamia by the Ottoman government, but the outbreak of WW I cancelled all plans of exploration - (Ferraro, Thompson)].

With this agreement the French control over Cilicia and Syria, Mosul granted in Iraq in part the British influence, France take share from the oil of Mosul, the British control Palestine. With this agreement the two countries fail to fulfil all their promises to the Arabs and ends UK's support to the Arab government in Damascus. See for details: Nevakivi, 1969, 90; Hurewitz, 1979, 30; Risley, 2010. 
At the same time the British after having failed to suppress the Bolshevik revolution in Russia supported in 1919 the Greek expansion into Asia Minor. The target was to secure their position in the oil fields of Mosul and the Persian Gulf, coming in contrast to the French allies, who had taken control of Syria. France also was not satisfied with the secondary role in the world oil, fearing the strength of British and American companies. In Syria, the French in the summer of 1920 were faced with the friend of UK King Faisal I, one of the four sons of Sheikh Hussein of Mecca ${ }^{10}$. To find support in their struggle but unable to cope against the Turkish nationalists too, they decided to end the war with Mustafa Kemal Pasha and to evacuate the occupied Cilicia, abandoning with their withdrawal war material ${ }^{11}$ as well. The resistance of the Turkish forces was a big surprise to France. Later the British forced to give Mustafa Kemal Pasha the Eastern Thrace too, after they managed to dominate in the oil fields of northern Iraq while supporting Faisal also: since he did not manage in Syria, he became king of Iraq and sent occupation troops to Mosul. British were no more interested in the Greek presence in Asia Minor, since the oil regions of the ex-Ottoman Empire belonged then to Iraq. Soon the latter became a mandate from the League of Nations British protectorate, in 1926.

According to Majeed (1997: 14) the British began negotiations with the Turkish nationalists (in Istanbul on 19 May 1924) and promised them the abolition of the idea of Kurdish state. In return they requested the annexation of Mosul in Iraq under British command and permission to establish military bases in Turkey (to protect the oilfields of the region from the danger of communism). Britain was anxious about the Turkish reaction after the breakdown of discussions.

But from the beginning the anti-imperialist agitation in Iraq troubled the British. London ruthlessly suppressed the uprising, including among others air strikes of villages in Iraq (as it had done a year ago to quell the unrest in Punjab). Greer writes (1991: 10) that in 1920, Churchill (Secretary of State for War and Air), suggests that Mesopotamia "could be

10 Lawrence had promised a kingdom for everyone, monarchs of the Arab states (Syria, Iraq, etc.) that would be created after the collapse of the Ottomans.

11 Knowing that this would be used against the Greek army. See Jensen, 1979, 561; Boinodiris, 2009, 121. In addition to the Treaty of Ankara in October 1921 French recognized the nationalist Turkish government in Ankara of Mustafa Kemal, essentially overturning the Treaty of Sevres.

France aimed to turn to address the Syrian Nationalists that argued categorically against Paris. They also wanted to secure the repayment of loans granted by the French banks, which were calculated at $60 \%$ of loans of the Ottoman Empire. 
policed by aircraft armed with cheap gas bombs, 4,000 British and 10,000 Indian soldiers", a policy formally adopted by Congress in 1921 to Cairo.

The arrangement of the San Remo between Britain and France excluded the USA oil companies from the energy resources of the region. Before the end of 1920, the American Press encouraged by the companies, denounced the Anglo-French agreement as an "oldfashioned imperialism". Washington made reference to sanctions and other measures against the "ungrateful" allies. Relations between Washington and London chilled to their coldest and a young lawyer at the State Department (Allen Dulles) drew up a memorandum insisting that the land concession to the Turkish Petroleum Company from the dismembered Ottoman Empire was legally invalid and should no longer be recognized by the USA. Soon London bowed to transatlantic tensions and indicated that it was ready for a deal that would give the U.S. a "fair" share.

Therefore, in accordance with the Treaty of Lausanne, signed on July 24, 1923, Britain and France agreed to share Kurdistan, in the newly created states of Iraq, Syria, Turkey, each having easy access to the sea. Consequently, in the same treaty, which replaced the Treaty of Sèvres, the establishment of an independent Kurdistan was cancelled. (Typically is noted that the word "Kurdistan" is not even mentioned in the Treaty of Lausanne). Britain claimed that Mosul belonged to Iraq and Turkey supported the province as part of its historical center. As a result, a three member Commission of the League of Nations was sent in 1924 to study the case and in 1925 it recommended that the area would be connected to Iraq, provided that Britain would carry out his mandate for Iraq for the next 25 years to ensure the rights of Kurdish autonomy. The Council approved the recommendation and decided on December 16, 1925 Mosul to be annexed to Iraq. On 17 December 1925, only one day after the League's decision, the Turkish Government signed a Neutrality and Non-Aggression Treaty with the Soviet Union. The Turkish officials believed that they were reacting to a resurgence of British imperialism. However, according to Klapsis (2012: 89) under the pressure of the diplomatic fait accompli of the decision by the League's Council, the Turks were forced to change their attitude, recognizing in June 1926 the concession of the biggest part of the Mosul region to the British Mandate of Iraq, and thus setting the start for the reestablishment of the relations between Ankara and London.

Note that the new state of the Soviet Union (SU) offered in the global market large quantities of oil at low prices. As a result in 1924 the West oil companies enhanced revolution in Caucasus, led by the exiled government of Georgia in Paris. The counterrevolution failed miserably and the West couldn't react for the Soviet oil although it was the first topic to discuss in the League of Nations. It is indicatively mentioned as one episode of the undeclared war for the Soviet oil (which covered a large part of consumption 
of Italy, France, Germany and other European countries) the sudden police investigation at the offices of the Soviet commercial delegation in London. On the pretext of various elements England broke off trade relations with the SU to stop the influx of Soviet oil even in England, although the capitalists had control over enormous oil companies by Henri Deterding.

Eventually the conflict for oil terminated in the Middle East with the division of 1928. A company created with the joint participation of British, French, Dutch and American and a businessman from the region (Gulbenkian) as follows: Anglo-Persian Oil Company, Royal Dutch Shell, Compagnie Française des Pétroles (Total), Near East Development Corporation, (union of five U.S. companies) from $23.75 \%$ and the Calouste Gulbenkian from $5 \%$. The relative agreement included the clause of the "Red Line". They draw on the map a red line that none of the parties had right to obtain exclusive concessions for research and oil holdings. In the restricted zone the Arabian Peninsula and the whole Asia Minor and Cyprus, except Kuwait were included. The agreement was kept until the WWII.

Falola \& Genova (2008: 68) indicate that "all the major oil agreements signed during the interwar period (with striking arrangements of the "Red Line" and of the Castle Achnacarry, in 1928), were either contracted between the above mentioned state-controlled companies, or dictated primarily by the energy and political - economic interests of Great Britain”.

Then the Anglo-American Petroleum Agreement (August 8, 1944) involved a failed attempt by the British and the American governments to establish a permanent agreement on the management of international supply and demand of oil. The Agreement would establish the International Petroleum Commission (IPC) for the purpose of balancing supply and demand, management of surplus and order and stability in a market with oversupply. The agreement was entirely opposed by the American oil industry, so the USA President Franklin Roosevelt withdrew and abandoned it.

We note the reaction of post-war Britain, to the nationalization and the eviction of the Anglo-Iranian Oil Company from Iran, by the country's Prime Minister Mossadeq. Note that the oil used in London during the decades, '20s '30s and '40s came only from Iran. UK imposed an economic blockade on Tehran and took refuge in the International Court of Justice, considering it a unilateral termination of the company's contract with the Iranian government. The court refused to intervene in the case which was an indirect vindication of the decision of Mossadeq. But without the experienced specialists from the West, the Iranians were not able to produce oil, in which the program of the Prime Minister would be based. In August 1952, the Parliament of Iran granted him extraordinary powers, but without the expected oil revenues was not able to implement his program. Promises to distribute 
large estates to the people remain unfulfilled. Political opposition, aided by the Shah, opposed vehemently against Mossadeq, so the Prime Minister came into conflict with the political leaders, the military, the judiciary and the Shah himself.

In August 1953 the Shah, worried about an imminent overthrow, endeavoured to push Mossadeq and appointed another Prime Minister. The people reacted, the Prime Minister was the provisional winner of the contest and the Shah was forced to leave Tehran as a refuge in Italy. But then after a coup organized from abroad ("Operation Ajax"), Mossadeq was eventually overthrown and the Shah returned in Tehran, (Zoula, 2004). The Anglo-Iranian Oil Company, which since 1954 was renamed into British Petroleum, (BP) granted in exchange to its new associates, the five largest oil companies in the US, the $40 \%$ of the Persian deposits, (Tsiaras, 2010). Competition between USA and Britain, though they belonged in the western camp, was concealed and focused on control of oil markets and increasing their political influence in this area. The company Aramco, of American interests, wanted to install the pipeline Tap from the region Al Zahra Saudi Arabia to the Mediterranean through Syria and Lebanon. Competitive Tapline pipeline in the Middle East was the MEPL pipeline of British Petroleum, through Iran to the Mediterranean. The negotiations about Tapline played a key role in USA - Syrians relations and USA - UK relationships.

Finally we record the opposition of the British and French to the nationalization of the Suez Canal by Nasser in August 1956. Until then it was operated as a French company based in Paris. The initiative that created obvious concern for causing generalized war in the region and brought them face to face with the USA. Washington has not only condemned the action of two key allies in the Western coalition, accusing them of "irrational reaction". USA demanded the immediate evacuation of the Port Said of the foreign troops stationed there. Tomai (2006) found that the Greek ambassador to Washington G. Melas warned that the threat of war had not disappeared and that the British planned a series of movements, such as incitement to the British pilots to strike, preparing the conditions for an armed intervention "lesser dislike in here" (meant USA).

\section{Epilogue}

The United Kingdom, fully rational to its strategy is preparing its next steps without losing any time. Even after the WW II and the emergence of the USA as one of the two power poles, London was immediately adjusted to the new facts, deciding to attach to the USA, decisively supporting the American foreign policy. In the post-war years, its oil independence was continued and after the energy crisis on 1973, thanks to the hydrocarbon exploitation of the North Sea. However, the expected consumption of those reserves will reset the issue of cheap energy resources pursuit and energy safety for the British policy. 
The cohesive geo-strategic model for Britain of energy inflow assurance from the Middle East is the fundamental component of its foreign policy in the region and it is based on the following parameters: (a) the assurance of the bases in Cyprus and further reinforcement of their state existence, (b) initiatives uptake in the wider region, [Grand British Initiative in the Middle East (GBIM)], (c) the utilization of the "Arab Spring" in Egypt, Libya and Syria mainly on the creation of a special relation with Turkey. So it will be emerged as a protagonist in the energy game in the region, (what unites Turkey and Israel, but also degrades them, is the desire to dominate in the region).

However, the crucial question is what wisdom can the United States draw from the British experience in Iraq from 1914-1928?

\section{References}

Antonius, G. (1969), The Arab Awakening, The Story of the Arab National Movement, Lebanon Bookshop, Beirut.

Bakanakis, S. \& M. Litsis \& M. Ketantzidis (2010), Oil, Gavriilidis, Athens.

Boinodiris, S. (2009), Andros Odyssey: Liberation: (1900-1940), iUniverse, Inc., NY.

Christodoulidis, Th. (1997), Diplomatic History, second vol., Sideris, Athens.

Falola, T. \& A. Genova (2008), The international Oil Policy, (K. Tourna, trans.), Papazisis, Athens.

Greer, E. (1991), “The Hidden History of the Iraq War”, Monthly Review, 43(1), 1-14.

Holt, P.M. (1966), Egypt and the Fertile Crescent 1516-1922, A Political History, Cornell University Press, Ithaca and London.

Hurewitz, J.C. (1979), "The Middle East and North Africa in World Politics", A Documentary Record, vol. 2, British-French Supremacy, 1914-1945, Yale University Press.

Karkazis, J. \& I. Vidakis \& G. Baltos (2010), "Geo-energy - a new reading of the world", Greek Defence \& Technology, 1(3), 104-113.

Majeed, K. (1997), Kurds and Oil: A study in the Iraq-Iran and Kuwaiti relation: Dar Al-Hikma, London.

Nevakivi, J. (1969), Britain, France and the Arab Middle East 1914-1920, The Athlone Press, London.

Sidebothan, H. (1938), Great Britain and Palestine, Macmillan, London.

Tsakiris, Th. (2008), "The Strategic Importance of Oil and Natural Gas for the Safety of the Great Powers from the World War I till the After Cold War Period", Unpublished PhD Thesis, PANTEION University of Social and Political Sciences, Athens.

Yergin, D. (1992), The Prize: The Epic Quest for Oil, Money and Power, Touchstone Books.

Churchill College Cambridge, Official: Admiralty: Admiral of the Fleet 1st Lord Fisher:

Correspondence, Reference code: CHAR 13/21, <http://wwwarchives.chu.cam.ac.uk/perl/node?a=a;reference=CHAR\%2013\%2F21>, 11.10.2013. 
Donovan, J. (2010, November 6), Royal Dutch Shell Nazi Secrets Part 1: The Funeral, <http://royaldutchshellplc.com/2010/11/06/royal-dutch-shell-nazi-secrets-part-1-thefuneral/>, 11.10.2013.

Engdahl, W.F. (2007, July 22), Oil and the origins of the 'War to make the world safe for Democracy', <http://www.engdahl.oilgeopolitics.net/History/Oil_and_the_Origins_of_World_W/oil_a nd_the_origins_of_world_w.HTM>, 11.10.2013.

Ferraro, V. (n.d.), "The International Petroleum Cartel”, Staff Report to the Federal Trade Commission, released through Subcommittee on Monopoly of Select Committee on Small Business, U.S. Senate, 83d Cong., 2nd sess (Washington, DC, 1952), Chapter 4, Joint Control Through Common Ownership-The Iraq Petroleum Co., Ltd.," pp. 47-112, Mount Holyoke College, <http://www.mtholyoke.edu/acad/intrel/Petroleum/ftc4.htm>, 14.10.2013.

Jensen, P.K. (1979), “The Greco-Turkish War, 1920-1922”, International Journal of Middle East Studies, Cambridge University Press, 10 (4), 553-565, <http://www.arts.yorku.ca/hist/tgallant/documents/jensengreco-turkishwar_000.pdf>, 14.10.2013.

Klapsis, A. (2012), “Turkey’s Search for a New Foreign Policy, 1923-1925: The View of Greek Diplomacy", Balkan Studies, 46, 81-98, <http://www.imxa.gr/files/BalkanStudies_\%285\%29\%20Klapsis\%20final\%20021012.pd $\mathrm{f}>, 14.10 .2013$.

Risley, D.B. (2010), "British Interests and the Partition of Mosul”, Thesis, The University of Texas, Austin, USA, <http://repositories.lib.utexas.edu/bitstream/handle/2152/ETD-UT-201005-904/RISLEY-THESIS.pdf?sequence=1>, 14.10.2013.

Thompson, E.V. (n.d.), “A Brief History Of Major Oil Companies In The Gulf Region”, Petroleum Archives Project, Arabian Peninsula \& Gulf Studies Program, University of Virginia, <http://www.virginia.edu/igpr/APAG/apagoilhistory.html>, 14.10.2013.

Tomai, F. (2006, November 26), The Suez Crisis, <http://www.tovima.gr/relatedarticles/article/?aid=177187>, 11.10.2013.

Tsiaras, G. (2010, June 27), BP A century conspiracies, political intrigue and ecological disaster for the sake of profit, <http://www.tovima.gr/world/article/?aid=340150>, 11.10.2013.

Zoula, I. (2004, January 18), Mohammad Mossadeq, For Iran's oil, <http://www.tovima.gr/relatedarticles/article/?aid=156521>, 11.10.2013. 
Vidakis, I. (2015), "The Origins of Energy Security: British Energy Policy in the Middle

East (Selling the Same Horse Three Times!)”, Sosyoekonomi, Vol. 23(25), 31-45. 